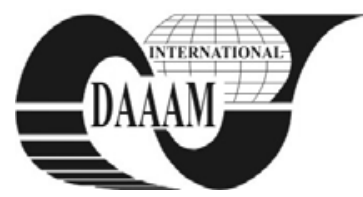

Annals of DAAAM for 2011 \& Proceedings of the 22nd International DAAAM Symposium, Volume 22, No. 1, ISSN 1726-9679 ISBN 978-3-901509-83-4, Editor B. Katalinic, Published by DAAAM International, Vienna, Austria, EU, 2011 Make Harmony between Technology and Nature, and Your Mind will Fly Free as a Bird Annals \& Proceedings of DAAAM International 2011

\title{
MIXING TECHNOLOGY IN HYDRAULIC TRANSPORT
}

\author{
HADZIAHMETOVIC, H[alima] \& DZAFEROVIC, E[jub]
}

\begin{abstract}
The mixing equipment is made of two main elements: an upper premixer consisting of two bolted parts. This premixer is lined with melted basalt plates on all sides where the wall of the equipment the built-in cone-deflector and the support elements of the cone is in contact with the slurry. This conditioner tank is made of wear-resisting hardox plate. Basic characteristic of this technology is mixing water with fly ash and bottom ash in ratio 1:1 and like dense slurry, with high pressure pumps, transported by pipeline to the disposal area. The essential characteristic of this technology is that it makes maximal use of the intrinsic property of ash, which tends to solidify in contact with water forming a steady and stable completely ambient-neutral rock mass.
\end{abstract}

Key words: mixing technology, hydraulic transport, fly ash, bottom ash

\section{INTRODUCTION}

In this paper, the description of mixing technology in the hydraulic transport of fly ash and bottom ash from thermal power plant. Using the most common transport and disposal of fly ash and water in ratio 1:15 creates water redundance, who drain to undergound and mixed with ground waters and pollute them. This environmental problems and water shortage are reason for reconstruction of existing system with new technology of dense slurry.

\section{BOTTOM ASH SILO AND ITS DISCHARGE}

\subsection{Bottom ash silo}

One bottom ash storage silo will be built with a total effective storage $(1500 \div 2500)$ capacity. The silo internal part is divided into two cells. Each cell has two conical bottom and includes two big size outlets to prevent bridging and provide proper outflow. To the outlets rood type closing device, and vibration feeders are connected. Under one cell at one time one vibrating feeder is operating only, the other serves as $100 \%$ reserve. The vibration feeders are motor operated and equipped with frequency controller to adjust the bottom ash flow required for dense slurry mixing and discharge. Vibration feeders are controlled by slurry flow meter and slurry density meter through PLC. The outlets of the bottom ash silos are equipped with water drenage system to route the water away coming out of the silo by gravity into the basin of water pump station (Hadziahmetovic, 2008).

\subsection{Discharge line to mixing technology}

A pneumatic operated diverter chute is placed under bottom the ash collection chute under the two feeder-valves, through which the discharged bottom ash falls down into one of the bottom ash crusher. The bottom ash -which is chopped further on in the crusher - gets through a pneumatic operated swinging ash damper and a special chute - which is equipped with a cleaning-door and a safety damper for water-outlet, - to the hydraulic ejector that mixing the bottom ash with the water, which is pumped from water basin of the water pump station. The ejectors transport the bottom ash slurry to the upper part of the premixers through bottom ash slurry pipes. With this bottom ash supply arrangement it is ensured that each of the mixing equipment are supplied with bottom ash identically. A pneumatic operated slurry gate valve is built in after the ejector in the slurry pipe-line in order to prevent the backflow at shutdown, since there is a pipe section upwards after the ejector. The pneumatic operated butterfly valves before the ejectors are interlocked together with the pneumatic slurry gate valves that are built in after the ejector, so that by opening the butterfly valve at the water-side the slurry gate valve after the ejector opens simultaneously and during the closing of the water-side butterfly valve the slurry gate valve closes.

\subsection{Emergency discharge to belt conveyor}

The bottom ash silo is equipped with emergency discharge facility. Below the two vibrating feeders, above the ash collecting chute there is sufficient space for two light structure movable belt conveyor. If from any reason the bottom ash silo to be emptied quickly into open trucks the stand-by movable belt-conveyors can be easily enrolled under the vibrating feeders and with the operation of both the vibration feeders the bottom ash silo cell can be emptied quickly (McGlinchey, 2008).

\section{MIXING TECHNOLOGY}

The production of bottom ash + fly ash and water of 1:1 mass-ratio is made by the mixing equipment. The mixing equipment is made of two main elements: an upper premixer consisting of two bolted parts (Wilson K.C. et al., 1997).

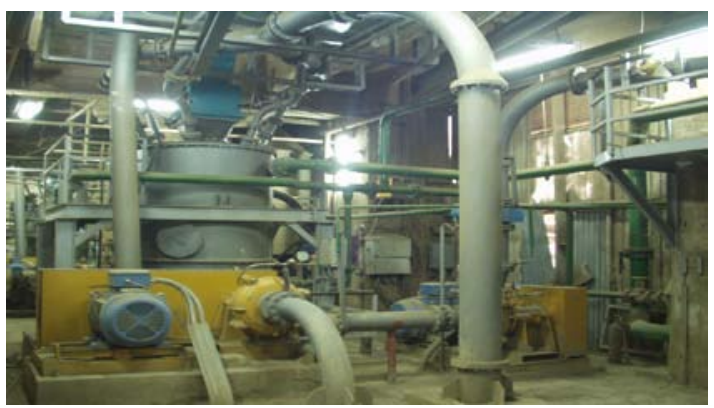

Fig. 1. Premixer and water slurry pumps

This premixer is lined with melted basalt plates on all sides where the wall of the equipment the built-in cone-deflector and the support elements of the cone is in contact with the slurry (Fig.1). This conditioner tank is made of wear-resisting hardox plate. The homogeneity of the bottom ash + fly ash slurry in it is ensured by a mixing agitator with a vertical axis. A slurrycirculate system provides the mixing of the fly ash. The recirculating slurry pump placed makes the suction from the discharge flange of the conditioner tank seated as well - the bottom ash-fly ash slurry through a main closing pneumatic 
operated slurry gate valve. The pipe is branched after the slurry pump. One of the pipes joins the long-distance slurry pumps, the other one connects after more branches to the nozzles mounted on the top of the upper part of the premixer. The dry fly ash falls down into the premixer with gravitation and will be mixed with the circulating slurry which is connected in 6 nozzles. The final mixing ratio can be set by the dosing of the bottom ash slurry mentioned before, and reserve water entered in the lower part of the premixer. Since the mixing of the circulating slurry and the fly ash entered in the premixer happens in several phases in the parts of the premixer and since the small part of aeration air of the fly ash silo and the discharge valves arrives here, an ventilating system is placed on the top of the conditioner tank. The ventilating system is built up of a wet scrubber and a suction fan. The dust particles coming with the air exhausted by the suction fan and separated in the scrubber, flows down as a slurry into the conditioner tank, while the clean air is pressed in the open air by the fan through a pipeline. The water supply of the scrubber is coming from the water pipe of the bottom ash ejectors. A pneumatic operated ball valve is built in the pipe-line (Hadziahmetovic et al., 2010).

The water required for mixing technology is supplied from the new water-basin. The water for the bottom ash transporting ejectors is supplied by two slurry pumps, one of which is in operation, the other is reserve. A non return valve and a pneumatic operated butterfly-valve is built in the pressure-pipe of the pumps. Both pumps can be connected to the bottom ash slurry transport system. This is guaranteed by the pneumatic operated butterfly-valve built in the connecting pipe and the two manual butterfly-valves. The pressure water pipe is connected to the ejectors transporting slurry by main pneumatic operated butterfly-valves. There is a branch from the pressure pipe towards the upper part of the premixer which operates when the bottom ash slurry transport is out of operation. A pneumatic operated butterfly-valve and a non- return valve is built in this by-pass pipe. Since the by-pass pipe has an open outlet towards the premixer, a nozzle has to be built in the pipe in order that the operating point of the pump does not change. A branch is made for the wet washer as well that is located on the slurry conditioner tank. A pneumatic operated butterflyvalve is built in the water pipe-line. The make-up water-supply of the slurry systems is ensured by two pumps, one of these is in operation, the other one is reserve during standard operation. A pneumatic operated butterfly-valve and a non-return valve is built in the pressure pipe of the pumps. Both pumps can be connected both slurry systems. This is ensured by the pneumatic operated butterfly-valve built in the connecting pipe, and furthermore the manual butterfly-valves. A pneumatic operated butterfly-valve and a non-return valve is built in the pressure-pipe connecting to the lower container of the premixer (Hadziahmetovic et al., 2010).

\section{SLURRY EMERGENCY DISCHARGE TO DRAIN PIT}

The two new drain pit will be located near the silos. In each drain pit there is one drain pumps. The pressure pipe of the drain pumps are connected to the two conditioner tanks.

\subsection{Slurry discharge line to disposal area}

Series of centrifugal slurry pumps and slurry valve arrangement. The recirculation slurry pipe after recirculation pump is branching towards the series of centrifugal pumps . For the long distance dense slurry transport to disposal area slurry pumps are connected in series (Wasp et al., 1977). Pumps are equipped with frequency converter. To fulfill all operational conditions such as min. and max. conveying distance min. and max. slurry flow all the slurry pumps are equipped with frequency converter. The slurry discharge line will be equipped with required Nos. of emergency emptying connection which will be connected to the drain pit. The slurry density is determined by the adjustment of the fly ash quantity. The fly ash quantity is adjusted by flow control valve. The flow control valve is controlled by the density meter in the long distance slurry pipeline. This closed loop control comes into automatic operation when bottom ash slurry feeding starts and remains in operation until bottom ash slurry feeding full stops.

\subsection{Ash slurry pipelines to the disposal area}

Both the circulating and the long-distance slurry pumps need gland seal water. The gland seal water system receives the supply water from the existing service water reservoir of bugger pump station. The water level of the gland seal water basin - which is placed inside silo on is controlled by level switches. Before and after the water pumps manual ball-valves and on the pressure-side a non return valve are built in. To each gland seal water pump pairs belong four pcs. pneumatic operated ball-valve, built in the pressure pipes. With these valves can changed automatically the other operating pump, in case a gland seal pump is out of operation. There is a water pressure regulating unit built in per pump directly in front of the slurry pumps.

\section{CONCLUSION}

Basic characteristic of this technology is mixing water with fly ash and bottom ash in ratio 1:1 and like dense slurry, with high pressure pumps, transported by pipeline to the disposal area. This is hydraulic transport and disposal with afterwards self solidification disposal material. This technology completely used fly ash and bottom ash characteristic and all negative influence on production are eliminated (like instability of disposal material, redundance of water used like transport medium and pollute water and air). Hydraulic transport of fly ash and bottom ash like dense slurry (in ratio 1:1) have next advantages: simple operation of facility, less of investments, minimum consumption of electricity required for transport, satisfy ecological standards, and simple service and minimum costs.

\section{REFERENCES}

McGlinchey, D. (2008). Bulk Solids Handling, WileyBlackwell, ISBN-10: 1405158255, United States

Hadziahmetovic H. (2008), Optimization of hydraulic transport of fly ash and bottom ash in the form of dense slurry/ Master's Thesis, Faculty of Mechanical Engineering Sarajevo, B\&H.

Hadziahmetovic H., Dzaferovic E., Cohodar M. (2010), Description of Technological Process of Hydraulic Transport From Thermal Power Plant, Annals of DAAAM \& Proceedings, 20-23rd October 2010, University of Zadar, Zadar, Croatia, Publisher: DAAAM International Vienna Audience, ISSN: 1726-9679, Katalinic, B. (Ed.), pp 685686

H. Hadziahmetovic H., Dzaferovic E., Cohodar M., Klaric S. (2010), System Of Fly Ash And Bottom Ash Transport From Thermal Power Plant, Proceedings of International Conference on Innovative Technologies IN-TECH, Prag, 14-16.09.2010., ISBN: 978-80-904502-2-6, Ing. Jan Kudlaček, pp 63-66

Wasp E.J et al. (1977), Solid-Liquid Flow Slurry Transportation, Bulk Materials Handling, Vol 1, No 4, Trans Tech Publications, ISBN-10: 0878490167, United States

Wilson K.C. et al. (1997), Slurry transport using centrifugal pumps, Blackie Academic \& Professional, London, UK 